\title{
Oil and Gas Projects in Sultanate of Oman: Construction Schedule and Cost Overrun
}

\author{
Hani Al Sadi ${ }^{1}$ and Mahmoud Dawood ${ }^{1 \#}$ \\ ${ }^{1}$ Middle East College, Muscat, Oman \\ \#Advisor
}

\section{$\underline{\text { ABSTRACT }}$}

Oil and Gas $(\mathrm{O} \& \mathrm{G})$ industry is the primary source of the gross national income in gulf area. This industry is facing construction related issues that lead to cost overrun and delay in construction schedule of the construction related tasks. During COVID 19 pandemic, Sultanate of Oman O\&G construction projects are facing many problems due to many factors. As a result and use these factors, about $70 \%$ of the major projects suffer from schedule slip and increasing costs. This has direct impact on the government budget with about $15 \%$ of GDP. This research is discussing the main factors and its root causes that have direct impact on construction cost and schedule for O\&G projects. This is has been done based on the literature and the conducted survey.

\section{Introduction}

Construction industry is an integral part of the economy of any country. Construction industry plays the main role in developing the infrastructure of any country (Shibnai Abdussalam and Salah Karim, 2016). The primary scope for any contractor and projects' owners (public and/or private) is to finish the project without negative impact on construction cost and time. One of the common challenge oil and gas industry is the fluctuation of oil prices. This is has negative impact on the industry construction sector. Oil and gas construction related industry field is one of the major industries on which the Omani economy depends (Ruqaishi \& Bashir, 2015). It is one of the most important source of GDP for Sultanate of Oman in terms of economy and development. Over the past fifty years, it is always common in oil and gas projects in the Sultanate of Oman the project exceeds the specified time (schedule) as well as the specified cost.

Schedule and cost Overrun is considered as the common critical problems facing oil and gas construction industry sector in the Sultanate of Oman. Schedule slip and cost overrun in projects leads to their failure unless the problems are addressed, as this will lead to negative impact on the company and the project in general as well. The stakeholder of any construction projected (not only Oil \& Gas sector) must be sufficiently aware of the factors that have direct impact on cost schedule. For oil and gas projects, cost and time performance are a source of concern for the government due to the uncertainty that characterizes these projects (Adam et al., 2017). Due to project management innovation related practices, there has been a tangible improvement in construction cost and schedule performance. Based on literature, oil and gas projects are subjected to cost overrun and schedule delay. Evaluating the source factors and root causes of oil and gas projects in Sultanate of Oman is the aim of this research.

In Sultanate of Oman, oil and gas construction projects are delaying with about 40 percent, which causes many problems between the project owner and the contractor by increasing requirements and time in the project (Umar, 2018). These problems negatively affect the contractor's reputation, which leads to a lack of their chances of obtaining future projects. It also might lead to bankruptcy and/or termination of contracts between owners (governments) and the construction company. The primarily significant of this research is evaluating the reasons of schedule and cost overrun in oil and gas construction sector in the Sultanate of Oman. This is will help in finding solutions to 
reduce the negative impact of such delay. This research is presenting a clear picture of the processes that can be adopted to reduce the problem of schedule and cost overrun in all projects.

\section{Research Methodology}

The research methodology has a major impact in determining the nature of the study. The methodology provides a theoretical understanding about the method or a set of methods used in the research. In order to achieve the research objectives, mix (quantitative and qualitative) method has been adopted. This will help in increasing the knowledge in managing the schedule and cost. A questionnaire has been developed and interviews have been conducted in order to collect the required data to be analysed. A pilot study has been conducted in order to check the effectiveness on the questionnaire design and its appropriate level. This provides an effective mechanisms to identify errors and amend them before continuing to the next step. It is effective strategy in order to reduce the unexpected problems that might face the research. A sample of questionnaires was given to professionals for their contribution to the research and the provision of relevant personal experience to be considered.

\section{General Causes of Schedule and Cost Overrun}

Construction parties are considered as the sources of reasons of schedule and cost overrun directly or indirectly in oil and gas projects (Bin Seddeeq et al., 2019). In addition, reasons might be internal or external. External reasons such as environmental reasons, government economy, state regulations, and/or economic market conditions. Internal reasons might be related to consultant (related to fault or incomplete designs, supervision, etc.) or the contractor (poor performance, resources issues, etc.). On the other hand, it might be related to the owner (scope creep, finance, etc.). Based on the literature, 70 percent of construction projects in Saudi Arabia exceed time and cost by 30\% (Bin Seddeeq et al., 2019). The causes are related to the contractor, customer, Consultant, equipment, contractual relationship, external factors, and construction resources (materials, work force, equipment, subcontractors, etc.). Generally, there are four main reasons for Schedule and cost overrun in oil and gas construction projects (Kazemi et al., 2018). These reasons are design change/errors, poor planning, lack of experiences, and inaccurate plans.

Design changes in the project by the owner Often Leads to change in the total of scope of work. This will effect between the complex nature of the project and the failure to make the final decision in the form and design of the project by the owner. Poor planning in the project schedule by the owner, consultant, or contractor, this issue causes the schedule and cost overrun due to the increased project duration and delay of project completion date. Errors in design by the consultant and the improper design strongly affects planning in the project schedule and leads to schedule and cost overrun by increasing the number of reviews in the design drawings and modifying them that leads to many adjustments in the construction stages especially in the advanced stages of the project. The participants experiences have major impact on the implementation of projects with great speed and completion on time without increasing costs and schedule. Lack of experience has a great impact on the life cycle of the project, which leads to project delays and an increase in the schedule and costs due to the lack of adequate experience in managing the projects (Amri \& Marey-Pérez, 2020). In addition, accurate planning is very important to avoid any additional costs. If the plan is generated without any detailed data, it will lead to not only cost and schedule overrun but also failure for the project.

\section{Impact of Schedule and Cost Overrun in Construction Projects}

Al-Suliman (2019) indicates that every project management department and higher departments should be concerned about all project costs before starting construction as if the costs exceed the target limit assigned, it will reduce the percentage of profits. In addition, it leads to decrease in confidence among customers, and this affecting the company's 
reputation as well. Increase the costs in any project that reduces revenue for the company, and this negatively affects the economic development of the company. To reduce costs, all stakeholders must follow policies that reduce the problem of increasing time and cost in projects by obtaining historical data for previous projects and obtaining a database of local costs for materials and equipment. In addition to choosing a project manager with sufficient experience to manage construction projects is very important aspect in oil and gas sector. On the other hand, it might lead to low work quality, loss of criticism, work interruption, loss of resources productivity and the late completion of the project.

\section{Mitigation of Cost Overrun and Schedule Delay}

Any construction project must be planned professionally. Not only planning but also implementation of the plans to achieve the project goals with respect to time and cost. Management must be vigilant to discover any excesses in the actual or potential cost during the construction process. According to Annamalaisami \& Kuppuswamy (2019), construction companies working in the field of construction must activate the system for creating cost graphs through analysis of graphs that will facilitate the audit process. The cost of the project can be controlled in the design phase and it is easy to provide information about the costs of the phases of the initial and future projects with the help of the design team. One way to help reduce project costs is to develop a risk management plan and a feasibility study before starting the project.

Construction engineers and architects must work together to complete the design drawings before preparing any estimates or contracts for the project to prevent the cost increase and increase the project duration. A risk analysis should be carried out by establishing the emergency plan (Durdyev, 2020). Appropriate funding must be identified for the project planning stage and ongoing training programs for work project operations and management to activate the system. Ensuring adequate funding, pre-planning tasks within the project, allocating sufficient time and money for the design stage, appointing a supervisory engineer for the project independently, selecting a qualified consultant and a reliable contractor are among of the most important points that have to be under spot to avoid cost and schedule issues. In addition, the owner of the project must develop an appropriate feasibility study and ensure that sufficient funds are available before starting the project. Contractors have to establish an efficient resource management system. Riazi \& Nawi (2018) confirmed that one of the best effective practices to improve work productivity is to establish a program of incentives and appreciation, to improve management and labour relations. In addition, providing appropriate accommodations for workers, providing distinctive logistical services, providing proper tools and equipment have direct impact on increasing their production rate.

\section{Main Causes of Schedule and Cost Overrun in Oil and Gas Projects in Oman}

Based on the conducted questionnaire and the interviews, the below tables are summarizing the factors that have direct impact on the cost and schedule overrun of oil and gas projects in Oman. In Table 1, the participants strongly agreed with the causes of schedule and cost overrun with an average of 4.54 to 5.00. Table below shows 17 main root causes of cost and schedule overrun.

Table 1: Main cases of cost and schedule overrun of oil and gas projects

\begin{tabular}{|c|c|c|c|c|c|}
\hline \multirow[t]{2}{*}{ Factor } & $\begin{array}{l}\text { Strongly } \\
\text { Disagree }\end{array}$ & Disagree & Neutral & Agree & $\begin{array}{l}\text { Strongly } \\
\text { Agree }\end{array}$ \\
\hline & Count & Count & Count & Count & Count \\
\hline Poor Coordination Between Contractor \& Client & 3 & 8 & 12 & 35 & 220 \\
\hline Lack of Expert & 1 & 6 & 12 & 68 & 191 \\
\hline
\end{tabular}




\begin{tabular}{|l|l|l|l|l|l|}
\hline Financial Problems with Contractor & 4 & 4 & 7 & 81 & 182 \\
\hline Weakness Planning and Scheduling & 1 & 8 & 12 & 94 & 163 \\
\hline HSE Problems & 5 & 6 & 14 & 93 & 160 \\
\hline Chang in Specification During Construction & 3 & 3 & 12 & 95 & 165 \\
\hline Shortage in Material \& Equipment & 6 & 6 & 10 & 84 & 172 \\
\hline Unexpected Weather Condition & 2 & 5 & 15 & 83 & 173 \\
\hline Poor Site Management and Performance & 4 & 2 & 6 & 88 & 178 \\
\hline Miss understanding of Clint requirements & 2 & 2 & 14 & 89 & 171 \\
\hline Labor Accident and Injuries & 2 & 10 & 20 & 68 & 178 \\
\hline Poor Monitoring and Control & 3 & 3 & 12 & 78 & 182 \\
\hline Design Issue & 3 & 5 & 12 & 70 & 188 \\
\hline increase the Scope \& additional requirements & 2 & 4 & 15 & 68 & 189 \\
\hline Inaccurate Engineering Estimate & 3 & 2 & 13 & 73 & 187 \\
\hline Poor feasibility Study & 2 & 4 & 11 & 72 & 189 \\
\hline Change Orders & 3 & 2 & 10 & 67 & 196 \\
\hline
\end{tabular}

The expected impacts of cost and schedule delays on oil and gas projects in Sultanate of Oman are shown in Table 2.

Table 3, shows the mitigation strategies and its effectiveness in minimizing the cost overrun and schedule delay.

Table 2: Cost overrun and schedule delays impacts

\begin{tabular}{|l|l|l|l|l|l|}
\hline Item & $\begin{array}{l}\text { No Im- } \\
\text { pact }\end{array}$ & $\begin{array}{l}\text { Slight im- } \\
\text { pact }\end{array}$ & $\begin{array}{l}\text { Moderate im- } \\
\text { pact }\end{array}$ & $\begin{array}{l}\text { High im- } \\
\text { pact }\end{array}$ & $\begin{array}{l}\text { Very high im- } \\
\text { pact }\end{array}$ \\
\cline { 2 - 6 } & Count & Count & Count & Count & Count \\
\hline Litigation between Contractor and Client & 4 & 3 & 30 & 40 & 201 \\
\hline Impact of work quality & 2 & 6 & 24 & 65 & 181 \\
\hline $\begin{array}{l}\text { Disputes and Claims between Contractor } \\
\text { and Client }\end{array}$ & 1 & 6 & 19 & 86 & 166 \\
\hline Impact in performance of the work & 4 & 9 & 24 & 95 & 146 \\
\hline completion project date & 2 & 15 & 16 & 89 & 156 \\
\hline payment delays & 2 & 5 & 20 & 77 & 174 \\
\hline Increase in overhead costs & 5 & 7 & 19 & 64 & 183 \\
\hline
\end{tabular}

Table 3: Mitigation strategies

\begin{tabular}{|l|l|l|l|l|l|}
\hline Item & $\begin{array}{l}\text { Not recom- } \\
\text { mended }\end{array}$ & $\begin{array}{l}\text { Slightly recom- } \\
\text { mended }\end{array}$ & $\begin{array}{l}\text { Moderately is } \\
\text { recommended }\end{array}$ & $\begin{array}{l}\text { Highly recom- } \\
\text { mended }\end{array}$ & $\begin{array}{l}\text { Very Highly } \\
\text { recommended }\end{array}$ \\
\cline { 2 - 6 } & Count & Count & Count & Count & Count \\
\hline $\begin{array}{c}\text { selecting an experienced } \\
\text { contractor \& consultant for } \\
\text { construction management }\end{array}$ & 8 & 4 & 10 & 30 & 226 \\
\hline $\begin{array}{c}\text { Implementing Value engi- } \\
\text { neering and cost reduction }\end{array}$ & 3 & 11 & 10 & 41 & 213 \\
\hline
\end{tabular}




\begin{tabular}{|c|c|c|c|c|c|}
\hline $\begin{array}{l}\text { Consider risk management } \\
\text { systems }\end{array}$ & 3 & 7 & 13 & 60 & 195 \\
\hline $\begin{array}{l}\text { Define project organization } \\
\text { / roles and responsibilities }\end{array}$ & 4 & 6 & 11 & 82 & 175 \\
\hline $\begin{array}{l}\text { Determine the correct Con- } \\
\text { tingency value / estimated } \\
\text { accuracy }\end{array}$ & 2 & 8 & 10 & 82 & 176 \\
\hline $\begin{array}{l}\text { Realistic project cost and } \\
\text { Schedule }\end{array}$ & 5 & 9 & 7 & 84 & 173 \\
\hline $\begin{array}{l}\text { Prepare an appropriate plan } \\
\text { for managing the operations } \\
\text { and procedures in the pro- } \\
\text { ject. }\end{array}$ & 2 & 13 & 8 & 67 & 188 \\
\hline $\begin{array}{l}\text { Use the appropriate soft- } \\
\text { ware to set up and control the } \\
\text { project schedule }\end{array}$ & 5 & 6 & 14 & 61 & 192 \\
\hline Clear scope of work & 3 & 10 & 11 & 67 & 187 \\
\hline $\begin{array}{l}\text { Conduct an early cost esti- } \\
\text { mate Kick-off Meeting }\end{array}$ & 3 & 3 & 16 & 67 & 189 \\
\hline $\begin{array}{l}\text { Prepare a responsibility ma- } \\
\text { trix for the team }\end{array}$ & 3 & 4 & 16 & 60 & 195 \\
\hline $\begin{array}{l}\text { Monitor progress and out- } \\
\text { puts through daily, weekly } \\
\text { and monthly progress reports }\end{array}$ & 2 & 6 & 11 & 56 & 203 \\
\hline
\end{tabular}

\section{Conclusion}

The aim of this research is to investigate the principal causes of schedule and cost overrun of oil and gas sector. The five top rated causes as per conducted survey was poor coordination, change orders, lack of expert, poor feasibility study, and inaccurate engineering estimate. The analysis shows the main reasons are contributed by the owner. In addition, the research assesses the impacts of schedule delay and cost overrun in oil and gas projects. The data analysis reveals that, where the respondent considered the highest overall rating for the impact as per the survey was litigation between contractor and client, impact of work quality during construction, payment delays from client to contractor, increase in overhead costs because of delaying in construction. In addition, the research pointed out the appropriate strategies to mitigate the schedule delay and cost overrun in oil and gas construction projects. The reasons have been linked to the low level of awareness of project management, and this problem can be solved by increasing the level of knowledge and efficient application of project management tools and techniques.

\section{References}

Adam, A., Josephson, P.-E. B., \& Lindahl, G. (2017). Aggregation of factors causing cost overruns and time delays in large public construction projects. Engineering, Construction and Architectural Management.

Alsuliman, J. A. (2019). Causes of delay in Saudi public construction projects. Alexandria Engineering Journal, 58(2), 801-808. 
Amri, T., \& Marey-Pérez, M. (2020). Towards a sustainable construction industry: Delays and cost overrun causes in construction projects of Oman. Journal of Project Management, 5(2), 87-102.

Annamalaisami, C. D., \& Kuppuswamy, A. (2019). Reckoning construction cost overruns in building projects through methodological consequences. International Journal of Construction Management, 1-11.

Bin Seddeeq, A., Assaf, S., Abdallah, A., \& Hassanain, M. A. (2019). Time and cost overrun in the Saudi Arabian oil and gas construction industry. Buildings, $9(2), 41$.

Durdyev, S. (2020). Review of construction journals on causes of project cost overruns. Engineering, Construction and Architectural Management.

Kazemi, A., Katebi, A., \& Kazemi, M.-H. (2018). Causes of delay in construction projects: the case of oil and gas projects. IJARE, 4,1 .

Riazi, S. R. M., \& Nawi, M. N. M. (2018). Project delays in the Malaysian public sector: causes, pathogens and the supply chain management approach. Industrial Engineering, 9(8).

Ruqaishi, M., \& Bashir, H. A. (2015). Causes of delay in construction projects in the oil and gas industry in the gulf cooperation council countries: a case study. Journal of Management in Engineering, 31(3), 5014017.

Shibnai Abdussalam and Salah Karim. (2016). Time and Cost Overrun in Construction Projects in Egypt Time and Cost Overrun in Construction Projects in Egypt Dr Abdussalam Shibnai Lecturer Coventry university, UK. SEPTEMBER 2015.

Umar, T. (2018). Causes of delay in construction projects in Oman. Middle East Journal of Management, 5(2), 121136. 